\title{
Dyeing Behaviors of Berberine, Palmatine, and Dye Extracted from Phellodendron Bark on Silk Fabric
}

\author{
Cheunsoon Ahn $\cdot$ Hye Ja Yoo ${ }^{* \dagger} \cdot$ Longchun Li \\ Dept. of Fashion Industry, University of Incheon \\ *Dept. of Clothing \& Textiles, Seowon University \\ Received July 17, 2012; Revised November 6, 2012; Accepted November 22, 2012
}

\begin{abstract}
The dyeing behaviors of berberine chloride, palmatine chloride hydrate, and Phellodendron bark extract on silk fabric were investigated to evaluate palmatine as another chromophoric substance of Phellodendron bark. The dyeing conditions were composed of combinations of $\mathrm{pH}(3,5,7,9)$, temperature $\left(10,30,55,80^{\circ} \mathrm{C}\right)$, and time $(10,30,60 \mathrm{~min})$. The results indicate that palmatine was comparable to berberine in the dyeing behaviors tested for this study and the results were statistically significant. The dye exhaustion and dye uptake of palmatine-CH were slightly lower than berberine- $\mathrm{C}$, which however were not statistically significant. Similar to berberine- $\mathrm{C}$, palmatine- $\mathrm{CH}$ favored a $\mathrm{pH} 7$ condition for both dye exhaustion and dye uptake. However, palmatine- $\mathrm{CH}$ favors a higher dyeing temperature and longer dyeing time than berberine- $\mathrm{C}$ for superior dyeing results.
\end{abstract}

Key words: Phellodendron Bark, Amur cork tree, Berberine, Palmatine, Natural dyeing

\section{Introduction}

Phellodendron bark, called cortex Phellodendri or Korean name hwangbek, is the dry bark of the cork tree such as the amur cork tree (Phellodendron amurense Rupr.) or the Chinese cork tree (Phellodendron chinense Shneid) (Chan et al., 2007; Hu et al., 2010). Its major chromophoric substance is known to be berberine which dyes fibers into yellow color. The quaternary ammonium cation of berberine enables the dye extracted from Phellodendron bark to have a high affinity to protein fibers such as silk and wool. Besides its usage as a natural dye, Phellodendron bark has been widely used as a source of traditional

\footnotetext{
${ }^{\dagger}$ Corresponding author

E-mail: hjyoo@seowon.ac.kr

This research was supported by Basic Science Research Program through the National Research Foundation of Korea (NRF) funded by the Ministry of Education, Science and Technology (2012007412).
}

medicine and its potential in the modern pharmaceuticals is increasing. The known medicinal effects of Phellodendron bark is summarized in the previous study (Ahn, 2011). Extensive studies in the pharmaceuticals revealed that the second abundant component of Phellodendron bark is palmatine and that it has similar antimicrobial effect and physical characteristics as berberine (Ahn, 2011). The compositions of berberine and palmatine in different species of Phellodendron bark were examined in various studies using different analytical methods. Some examples of the analytical results of the previous studies are summarized in $<$ Table $1>$.

Like berberine, palmatine is a crystal compound with yellow color (Lee et al., 2007), and considering the color of palmatine it is clear that palmatine should also be considered as a chromophoric substance in Phellodendron bark. Nonetheless, there has been only few studies which considered palmatine as the coloring component in Phellodendron bark. In the study

(C) 2012, The Korean Society of Clothing and Textiles. All rights reserved. 
Table 1. Composition of berberine and palmatine in Phellodendron bark as reported in previous literature

\begin{tabular}{c|c|c|c|c}
\hline \hline & Berberine & Palmatine & Solvent & Analysis \\
\hline Suto et al. (1997) & 10 times $\mathrm{x}$ & $\mathrm{x}$ & $\begin{array}{c}\text { methanol containing } \\
\text { dioctyl sodium } \\
\text { sulfosuccinate }\end{array}$ & $\begin{array}{c}2 \% \text { hydrochloric acid } \\
\text { IP-SFC }\end{array}$ \\
\hline Lee et al. (1999) & $0.5 \%$ & $0.2 \%$ & HPLC \\
\hline Hu et al. (2010) & $5.18 \%$ & $1.55 \%$ & methanol & HPLC-ESI MS \\
\hline Ahn et al. (2012) & $3230 \mu \mathrm{g} / \mathrm{L}$ & $1670 \mu \mathrm{g} / \mathrm{L}$ & HPLC-ESI MS \\
\hline
\end{tabular}

on the dyeing properties of Phellodendron bark extract on silk fabric Cho and Kang (2000) mentioned that the major coloring component of Phellodendron bark is berberine and minor components are palmatine and jatrorrhizine. However, the study focused only on the dyeing behaviors of Pellodendron bark extract but not on the dyeing behaviors of each coloring component in the plant. Other literatures which dealt with the dyeing behaviors of Phellodendron bark mentioned only of berberine as its coloring component, and did not mention the presence of palmatine in the plant nor its potential function as the coloring component (Kim \& Park, 2007; Kim \& Son, 2005; Kim et al., 2004).

However, the presence of palmatine as well as berberine in the Phellodendron bark dyed fabrics was confirmed in the previous literatures. Ahn et al. (2012) examined the methanolic solutions of berberine chloride, palmatine chloride hydrate, and Phellodendron bark extract and silk samples dyed with the same dyes using the high performance liquid chromatography tripled with a diode array detector and a electrospray ionization (ESI) mass selective analyzer (HPLCESI MS). In the study the compounds berberine and palmatine were simultaneously detected from the liquid dye and the dyed silk samples and the compositions of the two compounds were quantified based on their extract ion chromatograms (Ahn et al., 2012).

Considering the findings of the previous literatures, it is clear that equal attention should be given to palmatine as the dye component affecting the color and the dyeability of the textiles dyed with Phellodendron bark dye. And palmatine needs full attention in terms of its dyeing properties as a new natural dye material. In view of the previous findings, the purpose of the present research was to investigate the dy-

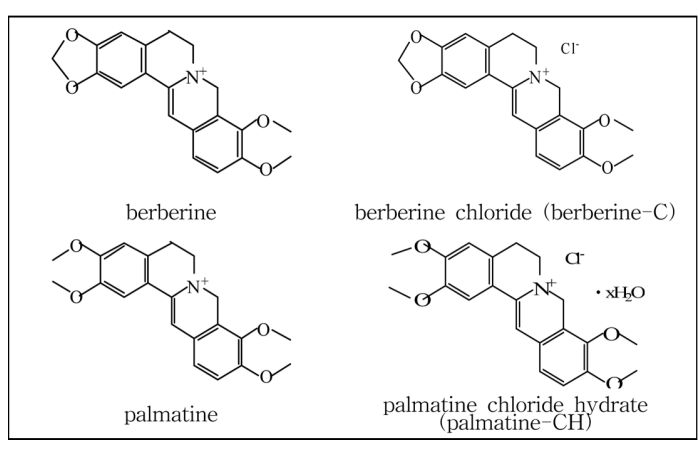

Fig. 1. Structures of berberine $\left(\mathrm{C}_{20} \mathrm{H}_{18} \mathrm{NO}_{4}{ }^{+}\right.$, molecular weight: 336.36$)$ and palmatine $\left(\mathrm{C}_{21} \mathrm{H}_{24} \mathrm{NO}_{4}{ }^{+}\right.$, molecular weight: 352.40 ) and their salts, berberine- $\mathrm{C}$ and palmatine- $\mathrm{CH}$.

eing behaviors of berberine, palmatine, and the dye extracted from Phellodendron bark on silk fabric with the intention of evaluating palmatine as another chromophoric substance of Phellodendron bark. Since berberine and palmatine are sold as salts- berberine chloride and palmatine chloride hydrate- and since the protoberberine alkaloids such as berberine and palmatine are known to exist in plant tissues in the form of salts (Grycova et al., 2007) the present investigation used berberine chloride and palmatine chloride hydrate as the berberine and palmatine dyes. Each is labeled berberine- $\mathrm{C}$ and palmatine- $\mathrm{CH}$ respectively in the following discussion. The chemical structure of berberine and palmatine and their salts are shown in $<$ Fig. $1>$.

\section{Experimental}

\section{Materials}

The Phellodendron bark was purchased from the 
Kyungdong traditional pharmaceutical market. berberine chloride (berberine-C) $\left(\mathrm{C}_{20} \mathrm{H}_{18} \mathrm{ClNO}_{4}\right.$, molecular weight: $371.81 \mathrm{~g} / \mathrm{mol}$, Natural yellow 18 ) and palmatine chloride hydrate (palmatine- $\mathrm{CH})\left(\mathrm{C}_{21} \mathrm{H}_{22} \mathrm{Cl}\right.$ $\mathrm{NO}_{4} \cdot \mathrm{xH}_{2} \mathrm{O}$, molecular weight: $405.87 \mathrm{~g} / \mathrm{mol}$, CAS 17 1869-95-7) were purchased from Sigma-Aldrich (USA). Bleached and scoured plain woven habutai silk with fabric count $104 \times 132 /$ inch $^{2}$ and weight $50.51 \mathrm{~g} / \mathrm{m}^{2}$ was purchased from Sombe Company (Korea). Glass fiber enhanced $0.45 \mu \mathrm{m}$ syringe filters were purchased from Alltech (Deerfield, IL, USA). Water used throughout the experiment was distilled using a water purification system by Human Corporation (Human Power, HM 1070522-508, Korea).

\section{Dyeing Procedure}

A 3L of stock solution was prepared for berberine$\mathrm{C}$ and palmatine- $\mathrm{CH}$. The stock volumes of berberine-C and palmatine- $\mathrm{CH}$ were used as the $\mathrm{pH} 7$ solutions without adjustment since their measured $\mathrm{pH}$ were 6.80 and 6.88 respectively. The $\mathrm{pH}$ was adjusted using acetic acid and $\mathrm{NaOH}$ solution. The actual $\mathrm{pH}$ of the adjusted volumes were $\mathrm{pH} 3.10$ (regarded as $\mathrm{pH} 3$ ), 5.03(5), and 9.03(9) for berberine dyebath, and $\mathrm{pH}$ 3.03(3), 5.08(5), and 9.02(9) for palmatine dyebath.

Washed and dried Phellodendron bark was powdered using a food chopper and sieved through a mesh with pore size $<0.5 \mathrm{~mm}$. A $140 \mathrm{~g}$ of Phellodendron bark powder was extracted two times using the distilled water each for $60 \mathrm{~min}$ at $80^{\circ} \mathrm{C}$ to obtain a total of 3.2L of dye liquor. The stock volume of Pellodendron bark was used as the $\mathrm{pH} 5$ solution since its measured $\mathrm{pH}$ was 5.06 . The actual $\mathrm{pH}$ values of the adjusted volumes were $\mathrm{pH} 3.02(3), 6.99(7)$, and 8.95 (9).

Dyeing was carried out using $100 \mathrm{~mL}$ beakers with lid. The dyeing conditions for berberine-C, palmatine- $\mathrm{CH}$, and Phellodendron bark were each composed of the combination of $\mathrm{pH}(3,5,7,9)$, temperature $\left(10,30,55,80^{\circ} \mathrm{C}\right)$, and time $(10,30,60 \mathrm{~min})$. The concentration of berberine- $\mathrm{C}$ and palmatine- $\mathrm{CH}$ dye was $2 \%$ o.w.f. and the liquor ratio was 1:100. Dyeing was conducted without mordanting to observe the dyeing behavior of the dyestuff itself. When dyeing was completed the samples were rinsed, drained, and dried in the air with minimum light exposure.

\section{Absorbance and Dye Exhaustion}

A Perkin Elmer Lambda 25 UV-Vis spectrophotometer was used to measure the absorbance of the dye liquors at $\lambda_{\max }$ before and after the dyeing. The standard curves of berberine and palmatine were made using the absorbances at $\lambda_{\max }$ of the $0.04,0.02$, $0.01 \mathrm{~g} / \mathrm{L}$ concentrations. Based on the standard curves, the extent of dye exhaustion $(\% E)$ was calculated using the following equation where $D_{o}$ was the concentration of dye in the initial dyebath and $D_{t}$ was the concentration of residual dyebath after dyeing (Kim et al., 2004).

$$
\% E=\frac{D_{o}-D_{t}}{D_{o}} \times 100
$$

\section{Colorimetric Measurement}

For each dyed sample, the color measurement was carried out using a JS-555 spectrocolorimeter (Color Techno System, Japan) under $\mathrm{D}_{65}$ illuminant and $10^{\circ}$ standard observer at three spots and the average data were reported.

\section{Statistical Analyses}

The statistical significances $(\alpha=0.05)$ of the differences in mean were tested using the ANOVA (Analysis of Variance) test of the SPSS 12.0 software. When Levene's test for the equality of variances was not accepted, the Kruskal Wallis tests was used instead of the ANOVA.

\section{Colorfastness Tests}

Dyed samples were tested for their colorfastness to sunlight, washing, perspiration, and drycleaning using the standard test methods of KS K ISO 105-B01 (former KS K 0699), KS K 0430, KS K ISO 105-E04, and KS K ISO 105-D01(former KS K 0644) respec- 
tively and the grey scale was used for evaluation. For each dye, the colorfastness tests were conducted on

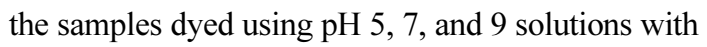
$55^{\circ} \mathrm{C}$ dyeing temperature and $30 \mathrm{~min}$ dyeing time.

\section{Results and Discussion}

\section{Analysis of the Stock Solutions}

The standard curves of berberine-C and palmatine$\mathrm{CH}$ were obtained based on the absorbance at $\lambda_{\max }$ which was $421 \mathrm{~nm}$ for all concentration levels (Fig. 2). Based on the curves, the concentrations of berberine- $\mathrm{C}$ or palmatine- $\mathrm{CH}$ in different $\mathrm{pH}$ solutions were calculated (Fig. 3). There was no difference in the concentrations of the dye according to the $\mathrm{pH}$ of the dyebaths. The result was in agreement with Battu et al. (2010) who reported that the solubility of berberine- $\mathrm{C}$ was independent of the $\mathrm{pH}$ levels 2.0-9.0 in phosphate buffers. The solubility of palmatine in water is said to be poor (Li et al., 2009) except when in hot water (LKT Laboratories, 2010; Santa Cruz Bio- technology, Inc., 2007-2012). However there was no available research reports on the solubility of palmatine in molar amounts. In the present study, the dye concentration of the stock solutions were $0.11 \mathrm{~g} / \mathrm{L}$ for berberine- $\mathrm{C}$ dye and $0.10 \mathrm{~g} / \mathrm{L}$ for palmatine- $\mathrm{CH}$ dye for all $\mathrm{pH}$ levels based on the absorbance at $\lambda_{\max }$. Although the stock solutions were prepared with the same gram amount of berberine- $\mathrm{C}$ and palmatine- $\mathrm{CH}$, the concentration of palmatine- $\mathrm{CH}$ was slightly lower than that of berberine-C. This is probably due to the fact that the palmatine- $\mathrm{CH}$ is a hydrate. As a hydrate, palmatine- $\mathrm{CH}$ contains a one to one ratio of a single molecule of water to a single molecule of palmatine chloride (Chromadex, Inc., 2011). Therefore, in the same gram amount of berberine- $\mathrm{C}$ and palmatine- $\mathrm{CH}$, there will be less palmatine chloride in palmatine- $\mathrm{CH}$ compared to berberine chloride in berberine-C.

The standard curve of Phellodendron bark dye was constructed assuming that the concentration of the total components extracted in the stock solution was 1 (Fig. 4(a)). Based on the standard curve the relative

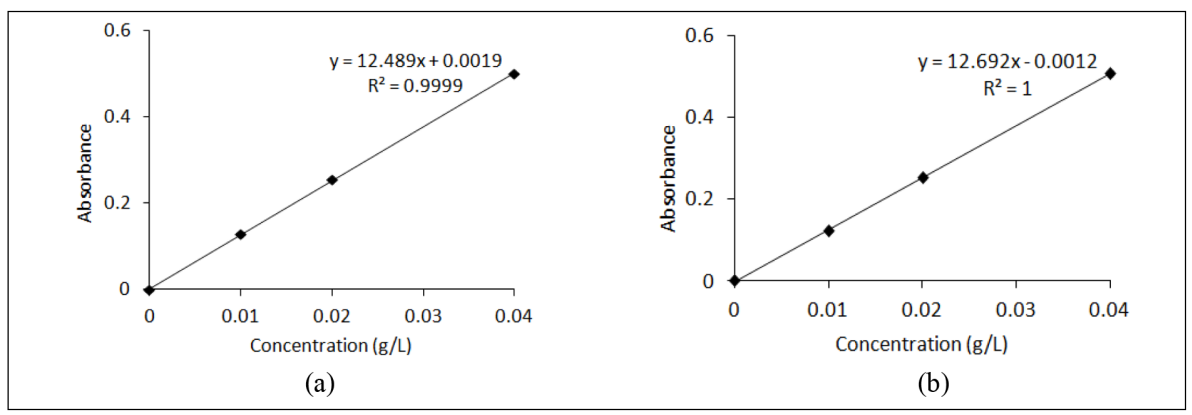

Fig. 2. Standard curves: (a) berberine-C, (b) palmatine-CH.

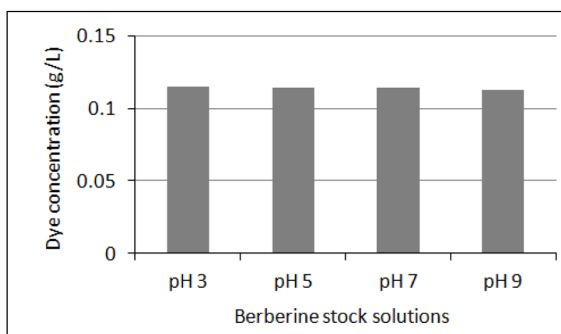

(a)

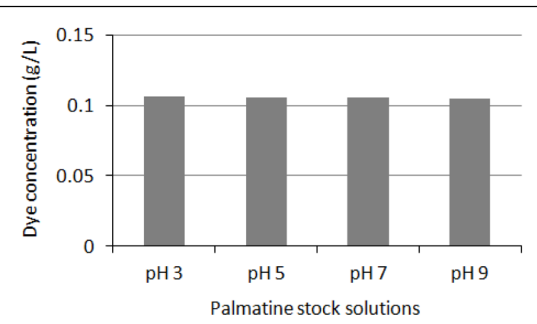

(b)

Fig. 3. Concentrations of the $\mathrm{pH}$ solutions: (a) berberine-C dye, (b) palmatine-CH dye. 
concentrations of Phellodendron bark in different $\mathrm{pH}$ solutions were deduced using the absorbance at $\lambda_{\max }$ which was 421-423nm (Fig. 4(b)).

Surprisingly, the relative concentration of Phellodendron bark extract increased with $\mathrm{pH}$ adjustments. The $\mathrm{pH}$ of the unadjusted Phellodendron bark solution was 5 and there was an evident increase in the

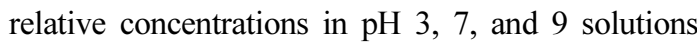
with the highest concentration observed in $\mathrm{pH} 9$. The same result was obtained in the repeated trials of extractions and $\mathrm{pH}$ adjustments. Considering the fact that the concentrations of neither berberine- $\mathrm{C}$ nor palmatine- $\mathrm{CH}$ were $\mathrm{pH}$ dependent, it is possible that the $\mathrm{pH}$ dependency of Phellodendron bark dyebath was due to the presence of components other than berberine- $\mathrm{C}$ and palmatine- $\mathrm{CH}$ in the plant extract. Possible components such as jatrorrhizine (Shaanxi Hongkang Biological Technology Co., Ltd., 19992010; Wei et al., 1998, brown-red powder) and tetrahydropalmatine (Hu et al., 2010, white or light yellow crystal) need to be investigated in the future research.

\section{Dye Exhaustion in Different Dyeing Conditions}

The extent of dye exhaustion in different dyeing conditions were first compared at the same $\mathrm{pH}$ level and dyeing time. The dyeing time of 10 min exhibited the lowest dye exhaustion for all $\mathrm{pH}$ levels and dyeing temperatures.

Berberine-C showed the highest dye exhaustion among the three dyes regardless of the $\mathrm{pH}$ level, dyeing temperature, and dyeing time (Fig. 5). Phelloden- dron bark showed the lowest dye exhaustion than berberine- $\mathrm{C}$ and palmatine- $\mathrm{CH}$ in all conditions. The low dye exhaustion of Phellodendron bark was due to higher concentration of Phellodendron bark dyebath compared to the concentration of berberine-C and palmatine-CH dyebaths.

When the $\mathrm{pH}$ of dye solution was 3 , the dye exhaustion was the lowest regardless of the dyeing time. When $\mathrm{pH} 3$ data were excluded from the data analyses, berberine- $\mathrm{C}$ and palmatine- $\mathrm{CH}$ showed the highest dye exhaustion at $55^{\circ} \mathrm{C}$ regardless of the $\mathrm{pH}$ conditions. The $55^{\circ} \mathrm{C}$ dyeing temperature was overall favorable to Phellodendron bark as well, although the $\mathrm{pH}$ had a more significant effect on Phellodendron bark.

To summarize the findings on the extent of dye exhaustion, the combination of dyeing conditions which gave the highest dye exhaustion was rank ordered and the top 10 ranks of berberine- $\mathrm{C}$, palmatine- $\mathrm{CH}$, and Phellodendron bark dyeing conditions are illustrated in $\langle$ Fig. 6$\rangle$. In both berberine-C and palmatine$\mathrm{CH}$, there were only slight differences in the extent of dye exhaustion within the top 10 ranked dyeing conditions. For all dyes, the most favored dyeing conditions appeared to be dyeing temperature $55^{\circ} \mathrm{C}$ for either $30 \mathrm{~min}$ or $60 \mathrm{~min}$ dyeing.

\section{Colorimetric Analyses}

The K/S values of the silk samples dyed with berberine-C, palmatine- $\mathrm{CH}$, and Phellodendron bark are presented in $\langle$ Table 2$\rangle$. As for berberine- $\mathrm{C}$, the highest $\mathrm{K} / \mathrm{S}$ value was observed in the silk dyed at $30^{\circ} \mathrm{C}$

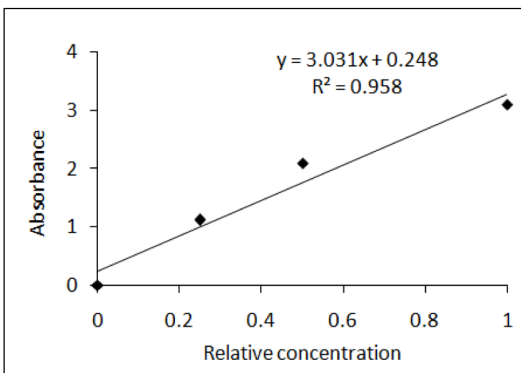

(a)

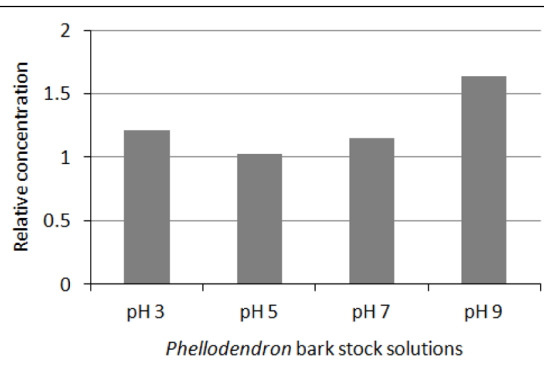

(b)

Fig. 4. (a) Standard curve of the Phellodendron bark solution. (b) Concentration of the pH solutions of the Phellodendron bark dyebaths. 


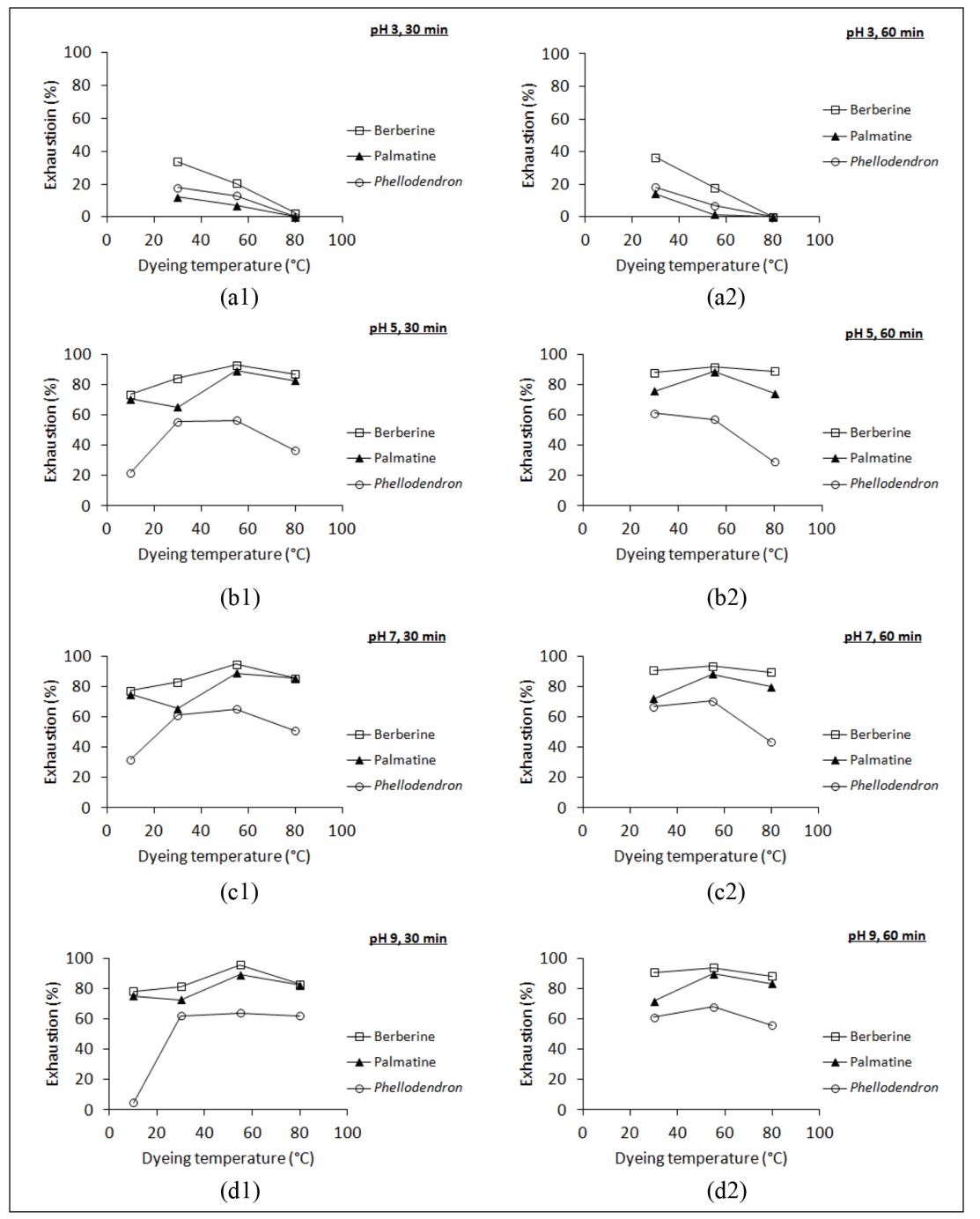

Fig. 5. Dye exhaustion at different dyeing temperatures when the $\mathrm{pH}$ and dyeing time were fixed.

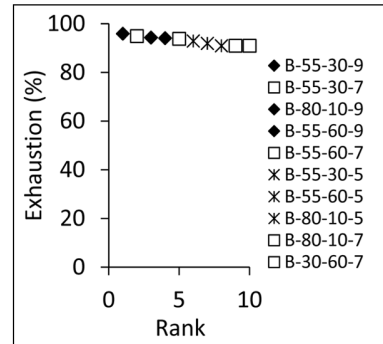

(a)

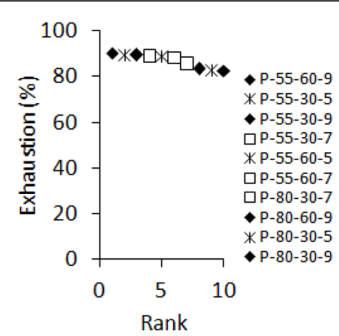

(b)

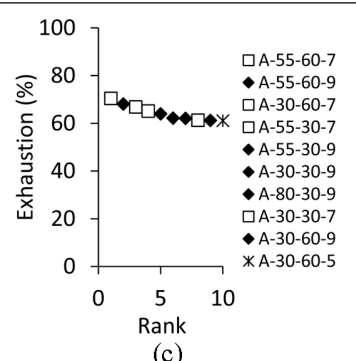

(c)

Fig. 6. Top 10 rankings of dye exhaustion: (a) berberine-C, (b) palmatine- $\mathrm{CH}$, (c) Phellodendron bark. The legend indicates, dye (B: berberine-C, P: palmatine- $\mathrm{CH}, \mathrm{A}$ : Phellodendron bark)-dyeing temperature-dyeing time$\mathrm{pH}$. 
for $60 \mathrm{~min}$ at $\mathrm{pH}$ 7. The highest $\mathrm{K} / \mathrm{S}$ value of palmatine- $\mathrm{CH}$ was observed in the silk samples dyed at $80^{\circ} \mathrm{C}$ for $30 \mathrm{~min}$ at $\mathrm{pH}$ 5. In case of Phellodendron bark, some samples resulted in extremely high $\mathrm{K} / \mathrm{S}$ values such as $55^{\circ} \mathrm{C}$ for $60 \mathrm{~min}$ at $\mathrm{pH} 9(\mathrm{~K} / \mathrm{S}=$ 4213.13). Such high $\mathrm{K} / \mathrm{S}$ value was due to the fact that the K/S values are calculated on the basis of the reflectance values, which in this cases were low as $0.01 \%$. It is known that the $\mathrm{K} / \mathrm{S}$ value grows to infinity as the reflectance value decreases to near 0 (Hunter-
Lab, 2008). The low dye exhaustion and yet such high $\mathrm{K} / \mathrm{S}$ values of Phellodendron bark indicates that the concentration of Phellodendron bark stock solution was unnecessarily high. The result suggests that the amount of plant material used for extraction should be lowered in the forthcoming dyeing trials. The presence of these K/S values which can act as outliers in the statistical analysis suggest that the color difference values $(\Delta E)$ should be used in accordance with the $\mathrm{K} / \mathrm{S}$ values in the examination of the extent

Table 2. Results of color analysis of dyed silk samples $\left(\lambda_{\max }: 440 \mathrm{~nm}\right)$

\begin{tabular}{|c|c|c|c|c|c|c|c|c|c|c|c|}
\hline \multirow{2}{*}{$\begin{array}{c}\text { Dyeing } \\
\text { temperature }\end{array}$} & \multirow{2}{*}{$\begin{array}{l}\text { Dyeing } \\
\text { time }\end{array}$} & \multirow{2}{*}{$\mathrm{pH}$} & \multicolumn{3}{|c|}{ Berberine } & \multicolumn{3}{|c|}{ Palmatine } & \multicolumn{3}{|c|}{ Phellodendron bark } \\
\hline & & & $\mathrm{K} / \mathrm{S}$ & R (\%) & $\Delta E$ & $\mathrm{~K} / \mathrm{S}$ & R (\%) & $\Delta E$ & $\mathrm{~K} / \mathrm{S}$ & $\mathrm{R}(\%)$ & $\Delta E$ \\
\hline \multirow{6}{*}{$10^{\circ} \mathrm{C}$} & \multirow{3}{*}{$10 \mathrm{~min}$} & 5 & 3.87 & 10.36 & 65.80 & 2.78 & 13.44 & 61.01 & 4.25 & 9.60 & 61.08 \\
\hline & & 7 & 4.16 & 9.76 & 68.72 & 2.92 & 12.94 & 60.32 & 4.94 & 8.46 & 64.14 \\
\hline & & 9 & 4.01 & 10.06 & 66.56 & 3.11 & 12.33 & 61.09 & 7.04 & 6.24 & 70.11 \\
\hline & \multirow{3}{*}{$30 \mathrm{~min}$} & 5 & 4.38 & 9.36 & 67.65 & 3.69 & 10.77 & 63.93 & 6.32 & 6.85 & 68.65 \\
\hline & & 7 & 4.23 & 9.63 & 67.10 & 3.75 & 10.64 & 63.78 & 7.82 & 5.68 & 74.28 \\
\hline & & 9 & 3.97 & 10.15 & 65.11 & 3.62 & 10.94 & 63.22 & 15.74 & 2.98 & 78.10 \\
\hline \multirow{12}{*}{$30^{\circ} \mathrm{C}$} & \multirow{4}{*}{$10 \mathrm{~min}$} & 3 & 1.33 & 22.54 & 45.77 & 0.55 & 36.56 & 28.64 & 2.84 & 13.23 & 52.31 \\
\hline & & 5 & 5.12 & 8.22 & 69.00 & 2.50 & 14.58 & 56.24 & 22.64 & 2.11 & 80.76 \\
\hline & & 7 & 8.97 & 5.02 & 74.56 & 3.33 & 11.69 & 63.18 & 61.28 & 0.80 & 84.69 \\
\hline & & 9 & 8.59 & 5.22 & 73.87 & 2.81 & 13.35 & 59.47 & 40.32 & 1.21 & 84.83 \\
\hline & \multirow{4}{*}{$30 \mathrm{~min}$} & 3 & 2.65 & 13.93 & 56.30 & 0.88 & 28.74 & 36.08 & 3.99 & 10.11 & 57.41 \\
\hline & & 5 & 7.21 & 6.11 & 75.29 & 3.58 & 11.04 & 63.97 & 32.19 & 1.50 & 82.70 \\
\hline & & 7 & 8.82 & 5.10 & 75.30 & 4.13 & 9.82 & 67.38 & 80.04 & 0.61 & 86.81 \\
\hline & & 9 & 6.00 & 7.18 & 72.62 & 4.79 & 8.70 & 68.12 & 228.86 & 0.21 & 89.27 \\
\hline & \multirow{4}{*}{$60 \mathrm{~min}$} & 3 & 2.63 & 14.02 & 57.95 & 0.73 & 31.70 & 37.88 & 5.40 & 7.85 & 58.87 \\
\hline & & 5 & 7.64 & 5.80 & 74.42 & 3.42 & 11.46 & 65.25 & 34.42 & 1.41 & 82.00 \\
\hline & & 7 & 15.22 & 3.08 & 81.77 & 3.65 & 10.85 & 66.38 & 47.44 & 1.03 & 85.94 \\
\hline & & 9 & 10.95 & 4.19 & 78.88 & 3.63 & 10.92 & 66.70 & 420.41 & 0.11 & 90.55 \\
\hline \multirow{12}{*}{$55^{\circ} \mathrm{C}$} & \multirow{4}{*}{$10 \mathrm{~min}$} & 3 & 1.37 & 22.06 & 47.63 & 0.66 & 33.40 & 31.75 & 3.98 & 10.10 & 54.40 \\
\hline & & 5 & 5.06 & 8.30 & 71.19 & 3.25 & 11.92 & 60.40 & 58.35 & 0.84 & 82.73 \\
\hline & & 7 & 7.92 & 5.62 & 74.95 & 4.36 & 9.40 & 65.62 & 58.35 & 0.84 & 82.89 \\
\hline & & 9 & 8.04 & 5.54 & 75.09 & 2.22 & 15.88 & 55.13 & 73.81 & 0.66 & 85.41 \\
\hline & \multirow{4}{*}{$30 \mathrm{~min}$} & 3 & 1.96 & 17.40 & 51.82 & 0.59 & 35.27 & 30.80 & 4.47 & 9.21 & 56.17 \\
\hline & & 5 & 11.28 & 4.07 & 80.25 & 5.22 & 8.08 & 70.76 & 29.25 & 1.65 & 79.11 \\
\hline & & 7 & 6.55 & 6.64 & 75.44 & 4.85 & 8.60 & 70.96 & 157.03 & 0.31 & 86.09 \\
\hline & & 9 & 7.61 & 5.82 & 77.48 & 5.10 & 8.24 & 70.45 & 75.62 & 0.65 & 86.00 \\
\hline & \multirow{4}{*}{$60 \mathrm{~min}$} & 3 & 2.03 & 16.93 & 51.20 & 0.59 & 35.12 & 31.34 & 4.09 & 9.91 & 52.63 \\
\hline & & 5 & 7.65 & 5.79 & 76.35 & 4.98 & 8.41 & 72.34 & 45.82 & 1.06 & 77.90 \\
\hline & & 7 & 6.67 & 6.54 & 76.74 & 5.26 & 8.02 & 73.03 & 267.98 & 0.18 & 83.88 \\
\hline & & 9 & 5.57 & 7.65 & 73.26 & 4.58 & 9.03 & 71.60 & 4213.13 & 0.01 & 86.60 \\
\hline
\end{tabular}


Table 2. Continued

\begin{tabular}{|c|c|c|c|c|c|c|c|c|c|c|c|}
\hline \multirow{2}{*}{$\begin{array}{l}\text { Dyeing } \\
\text { temp. }\end{array}$} & \multirow{2}{*}{$\begin{array}{l}\text { Dyeing } \\
\text { time }\end{array}$} & \multirow{2}{*}{$\mathrm{pH}$} & \multicolumn{3}{|c|}{ Berberine } & \multicolumn{3}{|c|}{ Palmatine } & \multicolumn{3}{|c|}{ Phellodendron bark } \\
\hline & & & $\mathrm{K} / \mathrm{S}$ & $\mathrm{R}(\%)$ & $\Delta E$ & $\mathrm{~K} / \mathrm{S}$ & $\mathrm{R}(\%)$ & $\Delta E$ & $\mathrm{~K} / \mathrm{S}$ & $\mathrm{R}(\%)$ & $\Delta E$ \\
\hline \multirow{12}{*}{$80^{\circ} \mathrm{C}$} & \multirow{4}{*}{$10 \mathrm{~min}$} & 3 & 1.21 & 23.87 & 45.06 & 0.35 & 43.93 & 25.14 & 1.90 & 17.70 & 44.51 \\
\hline & & 5 & 6.57 & 6.62 & 74.26 & 3.82 & 10.48 & 63.94 & 15.39 & 3.05 & 72.90 \\
\hline & & 7 & 7.79 & 5.70 & 76.46 & 3.84 & 10.43 & 64.96 & 17.10 & 2.76 & 77.78 \\
\hline & & 9 & 6.92 & 6.33 & 75.67 & 3.48 & 11.28 & 63.00 & 21.46 & 2.22 & 77.05 \\
\hline & \multirow{4}{*}{$30 \mathrm{~min}$} & 3 & 1.43 & 21.47 & 46.46 & 0.54 & 36.82 & 28.59 & 2.66 & 13.92 & 46.13 \\
\hline & & 5 & 7.45 & 5.93 & 77.37 & 6.39 & 6.79 & 69.74 & 27.67 & 1.74 & 76.22 \\
\hline & & 7 & 7.64 & 5.80 & 76.42 & 5.37 & 7.89 & 69.50 & 43.99 & 1.11 & 80.55 \\
\hline & & 9 & 7.77 & 5.72 & 76.89 & 3.63 & 10.92 & 66.33 & 43.99 & 1.11 & 82.10 \\
\hline & \multirow{4}{*}{$60 \mathrm{~min}$} & 3 & 1.06 & 25.83 & 44.73 & 0.71 & 32.08 & 34.13 & 3.08 & 12.43 & 48.08 \\
\hline & & 5 & 6.45 & 6.73 & 75.52 & 4.76 & 8.73 & 71.32 & 31.01 & 1.56 & 78.33 \\
\hline & & 7 & 8.64 & 5.19 & 76.33 & 5.80 & 7.38 & 72.57 & 72.93 & 0.67 & 83.32 \\
\hline & & 9 & 5.91 & 7.26 & 71.82 & 5.99 & 7.18 & 72.18 & 525.76 & 0.09 & 86.67 \\
\hline
\end{tabular}

of dye uptake. In all three dyes, silk dyed with $\mathrm{pH} 3$ dye solution showed the lowest K/S values regardless of the dyeing conditions.

From $<$ Table 2>, samples which show top $20 \mathrm{~K} / \mathrm{S}$ values of berberine- $\mathrm{C}$ and palmatine- $\mathrm{CH}$ were rank ordered in $\langle$ Fig. $7>$. In berberine-C dyed silk, the highest $\mathrm{K} / \mathrm{S}$ value was observed in the sample dyed in the $\mathrm{pH} 7$ bath $30^{\circ} \mathrm{C}$ for $60 \mathrm{~min}$. Its $\mathrm{K} / \mathrm{S}$ value was 1.3-1.4 times higher than the rank 2 sample and rank 3 sample. Excluding rank 1, 2, and 3 samples, any combination of dyeing time and temperature with $\mathrm{pH}$ 5-9 gave similar dye uptake with the standard deviation of only 0.70 . In palmatine dyed silk the highest $\mathrm{K} / \mathrm{S}$ value was observed in the silk sample dyed with $\mathrm{pH} 5,80$, for $30 \mathrm{~min}$. However the standard deviation of the top 20 ranked samples was only 0.83 indicat- ing that there were only slight differences in the dye uptake within the top 20 rank samples. The result indicates that similar to berberine-C any combination of dyeing temperature, dyeing time with the $\mathrm{pH}$ level 5-9 would give similar dye uptake with only small variance. Although there were slight differences in the ranking of the highest $\mathrm{K} / \mathrm{S}$ values and the highest dye exhaustion, the above results of K/S values were overall in agreement with the results of the dye exhaustion reported in the previous section.

In the silk dyed with Phellodendron bark, the highest $\mathrm{K} / \mathrm{S}$ value was observed in the sample dyed at $55^{\circ} \mathrm{C}$ for $60 \mathrm{~min}$ in $\mathrm{pH} 9$ dye bath, and four out of the top 6 samples were dyed in the $\mathrm{pH} 9$ dye bath (Fig. $8(\mathrm{a})$ ). When up to $30 \mathrm{~K} / \mathrm{S}$ rankings were examined, it was evident that the extent of dye uptake was signifi-

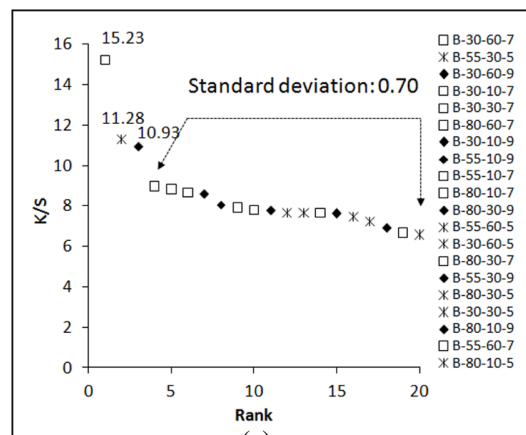

(a)

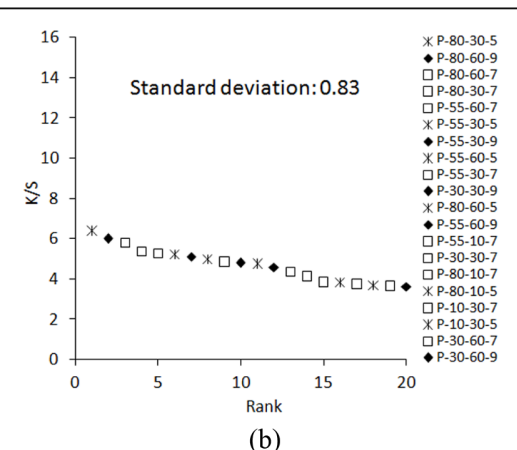

(b)

Fig. 7. Top $20 \mathrm{~K} / \mathrm{S}$ ranking of the dyed silk: (a) berberine-C, (b) palmatine-CH. The legend indicates, dye (B: berberine-C, P: palmatine-CH, A: Phellodendron bark)-dyeing temperature-dyeing time-pH. 
cantly related to the $\mathrm{pH}$ values and the dyeing time- in favor of a higher $\mathrm{pH}$ and a longer dyeing time (Fig. 8(b)). This result was in agreement with the results on the dye exhaustion of Phellodendron bark dye.

The Munsell hue of the silk dyed with berberine-C and palmatine- $\mathrm{CH}$ was in the range of $8.03 \mathrm{Y}-9.64 \mathrm{Y}$ and $8.00-\mathrm{S} 9.16 \mathrm{Y}$ respectively for the $\mathrm{pH} 5-7$ solutions regardless of dyeing temperature and dyeing time. In case of $\mathrm{pH} 3$ solution, the Munsell hue was 0.04GY-0.71GY for berberine-C, and 0.54GY-0.99GY for palmatine-CH. In Phellodendron bark however, all samples including the silk samples dyed with the pH 3 solution showed yellow hue and the hue values were in the range of $6.63 \mathrm{Y}-9.16 \mathrm{Y}$. $<$ Table $3>$ shows the mean color values of the silk dyed with the three dyes using the $\mathrm{pH} 5-7$ dyebath, $30-80^{\circ} \mathrm{C}$ dyeing temperature, and 30-60 min dyeing conditions.

\section{Statistical Analyses of Dye Exhaustion, K/S Values, and $\Delta E$ Values}

The ANOVA and the Kruskal Wallis test were conducted to see whether there were statistically significant differences in the dye exhaustion and the dye uptake among berberine-C, palmatine-CH, and Phellodendron bark. The extent of dye uptake was examined using the $\mathrm{K} / \mathrm{S}$ values and also the color difference values $(\Delta E)$. When three dyes were compared, berberine-C, palmatine- $\mathrm{CH}$, and Phellodendron bark showed significant differences in dye exhaustion, $\mathrm{K} /$ $\mathrm{S}$ values, and $\Delta E$ at $\alpha<.001$ (Table 4). The Duncan's post-hoc test indicated that Phellodendron bark was different from berberine-C and palmatine- $\mathrm{CH}$. The highest mean $\mathrm{K} / \mathrm{S}$ value was observed in Phellodendron bark while the lowest mean $\mathrm{K} / \mathrm{S}$ value was observed in palmatine- $\mathrm{CH}$. The background for low dye exhaustion yet high K/S values of the Phellodendron bark was discussed above.

When each dye was analyzed separately to single out the most influential dyeing condition which affected the dye exhaustion and the dye uptake, it was found that the $\mathrm{pH}$ of the dyebath was the most significant factor by $p<.001$ for all three dyes (Table 5). The Duncan's post-hoc test showed that the $\mathrm{pH} 3$ bath condition was different from the other $\mathrm{pH}$ levels, pH 3 showing the lowest mean values. In berberine- $\mathrm{C}$ and palmatine- $\mathrm{CH}$, the $\mathrm{pH}$ condition which showed the highest $\mathrm{K} / \mathrm{S}$ values and $\Delta E$ values was

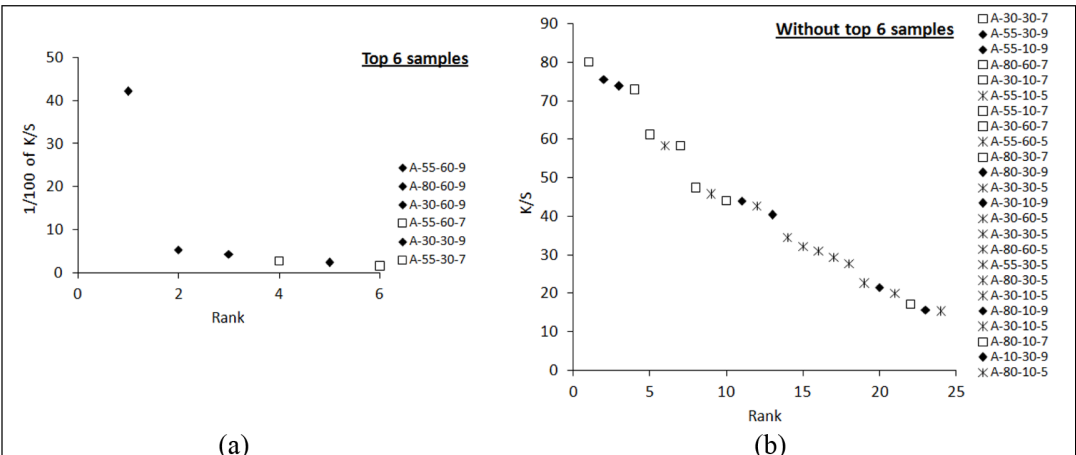

Fig. 8. K/S ranking of the silk dyed with Phellodendron bark: (a) top 6 rankings, (b) up to 30 rankings. The legend indicates, dye (B: berberine-C, P: palmatine-CH, A: Phellodendron bark)-dyeing temperature-dyeing time-pH.

Table 3. Mean color values of silk dyed with three dyes

\begin{tabular}{c|c|c|c|c|c}
\hline \hline & $\mathrm{L}$ & $\mathrm{a}$ & $\mathrm{b}$ & $\mathrm{H}$ & $\mathrm{V} / \mathrm{C}$ \\
\hline Berberine-C & 89.41 & -8.65 & 74.84 & $8.53 \mathrm{Y}$ & $8.81 / 11.15$ \\
\hline Palmatine-CH & 89.18 & -8.78 & 72.61 & $8.59 \mathrm{Y}$ & $8.80 / 10.32$ \\
\hline Phellodendron bark & 78.28 & -4.22 & 85.68 & $6.87 \mathrm{Y}$ & $7.68 / 12.16$ \\
\hline
\end{tabular}

Samples were dyed using pH 5-7 dyebath at $30-80^{\circ} \mathrm{C}$ for $30-60$ minutes. 
Table 4. Result of statistical test for the differences among the standard dyes and the plant extract

\begin{tabular}{|c|c|c|c|c|}
\hline Factor $\quad$ Statistical & $\begin{array}{c}\text { Berberine-C } \\
(\mathrm{N}=42)\end{array}$ & $\begin{array}{l}\text { Palmatine-CH } \\
(\mathrm{N}=42)\end{array}$ & $\begin{array}{l}\text { Phellodendron } \\
\text { bark }(\mathrm{N}=42)\end{array}$ & $\begin{array}{l}\text { Statistics } \\
\text { (p-value) }\end{array}$ \\
\hline Dye exhaustion & $\begin{array}{c}69.70^{1)} \\
(30.76) \\
a^{2)}\end{array}$ & $\begin{array}{c}58.30 \\
(34.44) \\
a\end{array}$ & $\begin{array}{c}37.63 \\
(25.21) \\
\mathrm{b}\end{array}$ & $\begin{aligned} \mathrm{F}= & 12.03 * * \\
& (.000)\end{aligned}$ \\
\hline $\mathrm{K} / \mathrm{S}$ & $\begin{array}{c}5.96 \\
(3.07)\end{array}$ & $\begin{array}{c}3.34 \\
(1.70)\end{array}$ & $\begin{array}{c}162.50 \\
(649.46)\end{array}$ & $\begin{array}{c}\chi^{2}=49.43^{* *} \\
\quad(.000)\end{array}$ \\
\hline Color difference $(\Delta E)$ & $\begin{array}{c}68.69 \\
(10.93) \\
a\end{array}$ & $\begin{array}{c}58.53 \\
(14.62) \\
a\end{array}$ & $\begin{array}{c}74.28 \\
(13.33) \\
b\end{array}$ & $\begin{aligned} \mathrm{F}= & 15.43^{* *} \\
& (.000)\end{aligned}$ \\
\hline
\end{tabular}

${ }^{1)}$ Mean value and the standard deviation in parenthesis.

${ }^{2)}$ Different alphabet in the cell indicates different groups according to the Duncan test.

Table 5. Statistical analyses of the standard dyes and plant extract when pH 3 data are included

\begin{tabular}{|c|c|c|c|c|c|c|c|c|}
\hline \multirow{2}{*}{ Dye } & \multirow{2}{*}{ Factor } & \multirow{2}{*}{$\begin{array}{c}\begin{array}{c}\text { Dyeing } \\
\text { temperature }\end{array} \\
\begin{array}{c}\text { Statistics } \\
\text { (p-value) }\end{array} \\
\end{array}$} & \multirow{2}{*}{$\begin{array}{c}\begin{array}{c}\text { Dyeing } \\
\text { time }\end{array} \\
\begin{array}{c}\text { Statistics } \\
\text { (p-value) }\end{array}\end{array}$} & \multicolumn{5}{|c|}{$\mathrm{pH}$ of dye solution } \\
\hline & & & & $\mathrm{pH} 3$ & $\mathrm{pH} 5$ & pH 7 & $\mathrm{pH} 9$ & $\begin{array}{l}\text { Statistics } \\
\text { (p-value) }\end{array}$ \\
\hline \multirow{3}{*}{$\begin{array}{c}\text { Berberine-C } \\
(\mathrm{N}=42)\end{array}$} & $\begin{array}{c}\text { Dye } \\
\text { exhaustion }\end{array}$ & $\begin{array}{c}\chi^{2}=4.79 \\
(.188)\end{array}$ & $\begin{array}{l}\mathrm{F}=.09 \\
(.918)\end{array}$ & $\begin{array}{c}18.13^{2)} \\
(12.63) \\
\mathrm{a}^{3)}\end{array}$ & $\begin{array}{c}83.13 \\
(9.80) \\
b\end{array}$ & $\begin{array}{c}85.16 \\
(8.37) \\
b\end{array}$ & $\begin{array}{c}85.22 \\
(8.30) \\
b\end{array}$ & $\begin{aligned} \mathrm{F}= & 108.95^{* *} \\
& (.000)\end{aligned}$ \\
\hline & $\mathrm{K} / \mathrm{S}$ & $\begin{array}{c}\chi^{2}=4.63 \\
(.201)\end{array}$ & $\begin{array}{l}\mathrm{F}=.59 \\
(.559)\end{array}$ & $\begin{array}{c}1.75 \\
\left(\begin{array}{l}.60) \\
\mathrm{a}\end{array}\right.\end{array}$ & $\begin{array}{c}6.61 \\
(2.05) \\
b\end{array}$ & $\begin{array}{c}7.88 \\
(2.95) \\
\mathrm{b}\end{array}$ & $\begin{array}{c}6.85 \\
(2.06) \\
\mathrm{b}\end{array}$ & $\begin{array}{c}\mathrm{F}=15.54^{* *} \\
\quad(.000)\end{array}$ \\
\hline & $\Delta E$ & $\begin{array}{c}\chi^{2}=3.98 \\
(.264)\end{array}$ & $\begin{array}{l}F=.29 \\
(.754)\end{array}$ & $\begin{array}{c}49.66 \\
(4.94) \\
a \\
\end{array}$ & $\begin{array}{c}73.37 \\
\left(\begin{array}{c}4.43) \\
\mathrm{b}\end{array}\right. \\
\end{array}$ & $\begin{array}{c}74.89 \\
(3.96) \\
\mathrm{b}\end{array}$ & $\begin{array}{c}73.39 \\
(4.30) \\
\mathrm{b} \\
\end{array}$ & $\begin{array}{c}\mathrm{F}=71.91 * * \\
\quad(.000)\end{array}$ \\
\hline \multirow{3}{*}{$\begin{array}{l}\text { Palmatine-CH } \\
\qquad(\mathrm{N}=42)\end{array}$} & $\begin{array}{c}\text { Dye } \\
\text { exhaustion }\end{array}$ & $\begin{array}{c}\chi^{2}=4.70 \\
(.195)\end{array}$ & $\begin{array}{l}F=.27 \\
(.768)\end{array}$ & $\begin{array}{c}5.94 \\
(5.67) \\
a\end{array}$ & $\begin{array}{c}73.59 \\
(11.47) \\
b\end{array}$ & $\begin{array}{c}76.30 \\
(8.84) \\
b\end{array}$ & $\begin{array}{c}74.40 \\
(12.87) \\
\mathrm{b}\end{array}$ & $\begin{aligned} \mathrm{F}= & 105.86^{* *} \\
& (.000)\end{aligned}$ \\
\hline & $\mathrm{K} / \mathrm{S}$ & $\begin{array}{c}\chi^{2}=3.02 \\
(.389)\end{array}$ & $\begin{array}{c}\mathrm{F}=1.89 \\
(.164)\end{array}$ & $\begin{array}{c}.63 \\
(.15)\end{array}$ & $\begin{array}{c}4.04 \\
(1.17)\end{array}$ & $\begin{array}{c}4.30 \\
(.92)\end{array}$ & $\begin{array}{c}3.91 \\
(1.10)\end{array}$ & $\begin{array}{c}\chi^{2}=21.75^{* * *} \\
(.000)\end{array}$ \\
\hline & $\Delta E$ & $\begin{array}{c}\chi^{2}=2.11 \\
(.550)\end{array}$ & $\begin{array}{l}\mathrm{F}=.79 \\
(.462)\end{array}$ & $\begin{array}{c}31.59 \\
(3.97) \\
\mathrm{a}\end{array}$ & $\begin{array}{c}65.35 \\
(5.15) \\
b\end{array}$ & $\begin{array}{c}67.06 \\
(4.07) \\
b\end{array}$ & $\begin{array}{c}65.21 \\
(5.38) \\
b\end{array}$ & $\begin{aligned} \mathrm{F}= & 124.71 * * \\
& (.000)\end{aligned}$ \\
\hline \multirow{3}{*}{$\begin{array}{c}\text { Phellodendron } \\
\text { bark } \\
(\mathrm{N}=42)\end{array}$} & $\begin{array}{c}\text { Dye } \\
\text { exhaustion }\end{array}$ & $\begin{array}{c}\mathrm{F}=3.26^{*} \\
(.032)\end{array}$ & $\begin{array}{l}\mathrm{F}=.58 \\
(.563)\end{array}$ & $\begin{array}{c}9.33 \\
\left(\begin{array}{c}7.55) \\
\mathrm{a}\end{array}\right. \\
\end{array}$ & $\begin{array}{c}41.82 \\
(15.65) \\
b\end{array}$ & $\begin{array}{c}50.11 \\
(16.67) \\
b\end{array}$ & $\begin{array}{c}48.18 \\
(23.51) \\
b\end{array}$ & $\begin{array}{c}\mathrm{F}=12.79 * * \\
\quad(.001)\end{array}$ \\
\hline & $\mathrm{K} / \mathrm{S}$ & $\begin{array}{c}\chi^{2}=6.47 \\
(.091)\end{array}$ & $\begin{array}{c}\mathrm{X}^{2}=3.81 \\
(.149)\end{array}$ & $\begin{array}{l}3.60 \\
(1.07)\end{array}$ & $\begin{array}{c}27.94 \\
(15.91)\end{array}$ & $\begin{array}{c}74.45 \\
(76.78)\end{array}$ & $\begin{array}{c}515.11 \\
(1239.07)\end{array}$ & $\begin{array}{c}\chi^{2}=23.62 * * \\
(.000)\end{array}$ \\
\hline & $\Delta E$ & $\begin{array}{l}\mathrm{F}=.88 \\
(.462)\end{array}$ & $\begin{array}{l}\mathrm{F}=.44 \\
(.647)\end{array}$ & $\begin{array}{c}52.28 \\
(5.07) \\
a\end{array}$ & $\begin{array}{c}76.58 \\
(6.71) \\
b\end{array}$ & $\begin{array}{c}80.94 \\
(6.74) \\
b c\end{array}$ & $\begin{array}{c}83.34 \\
(6.05) \\
c\end{array}$ & $\begin{array}{c}\mathrm{F}=49.80 * * \\
\quad(.000)\end{array}$ \\
\hline
\end{tabular}

${ }^{11}$ Kruskal Wallis $\left(\chi^{2}\right)$ test was conducted instead of ANOVA (F value) when the Levene's test for the equality of variances was rejected.

${ }^{2)}$ Mean value and the standard deviation in parenthesis.

${ }^{3)}$ Different alphabet in the cell indicates different groups according to a Duncan test. 
showed the highest $\mathrm{K} / \mathrm{S}$ values and $\Delta E$ values was $\mathrm{pH}$ 9. In berberine-C and Phellodendron bark, there was a slight discrepancy between the statistical results of $\mathrm{K} / \mathrm{S}$ values and the dye exhaustion. In berberine$\mathrm{C}, \mathrm{pH} 9$ showed the highest mean dye exhaustion while $\mathrm{pH} 7$ showed the highest K/S value. In Phellodendron bark, it was the opposite. However, based on the Duncan's post-hoc test there was no statistical difference among $\mathrm{pH} 5,7$, and 9 for both berberine-C and Phellodendron bark.

When $\mathrm{pH} 3$ was excluded from the data analysis, the factor which was most influential to the dye exhaustion and the dye uptake was the dyeing temperature, which showed statistical significance by $p<$
.01 for all three dyes (Table 6). The result indicated that $10^{\circ} \mathrm{C}$ dyeing was the least favorable to all three dyes. In berberine-C, the highest mean $\mathrm{K} / \mathrm{S}$ and $\Delta E$ values were examined in $30^{\circ} \mathrm{C}$ dyeing while in Phellodendron bark the mean dye exhaustion and $\mathrm{K} / \mathrm{S}$ value were the highest in $55^{\circ} \mathrm{C}$ dyeing. However, according to the Duncan's post-hoc test there was no notable difference among $30^{\circ} \mathrm{C}, 55^{\circ} \mathrm{C}$, and $80^{\circ} \mathrm{C}$ dyeing temperatures for both dyes. In palmatine- $\mathrm{CH}$ the highest mean $\mathrm{K} / \mathrm{S}$ and $\Delta E$ values were observed in $80^{\circ} \mathrm{C}$ dyeing with little to no difference with $55^{\circ} \mathrm{C}$ dyeing. Different from the other dyes, palmatine- $\mathrm{CH}$ also showed the significant difference in dyeing time by $p<.01$ (Table 7). The higher dye exhaustion and dye

Table 6. Statistical analyses of the standard dyes and plant extracts without the pH 3 data

\begin{tabular}{|c|c|c|c|c|c|c|c|c|}
\hline \multirow{2}{*}{ Dye } & \multirow{2}{*}{ Factor } & \multicolumn{5}{|c|}{ Dyeing temperature $\left({ }^{\circ} \mathrm{C}\right)$} & \multirow{2}{*}{$\begin{array}{c}\text { Dyeing time } \\
\text { Statistics } \\
\text { (p-value) }\end{array}$} & \multirow{2}{*}{$\begin{array}{c}\mathrm{pH} \text { of dye } \\
\text { solution } \\
\begin{array}{c}\text { Statistics } \\
\text { (p-value) }\end{array}\end{array}$} \\
\hline & & 10 & 30 & 55 & 80 & $\begin{array}{l}\text { Statistics }^{1)} \\
\text { (p-value) }\end{array}$ & & \\
\hline \multirow{3}{*}{$\begin{array}{c}\text { Berberine-C } \\
(\mathrm{N}=33)\end{array}$} & $\begin{array}{c}\text { Dye } \\
\text { exhaustion }\end{array}$ & $\begin{array}{c}\left.14.37^{2}\right) \\
(11.50) \\
\mathrm{a}^{3}\end{array}$ & $\begin{array}{c}56.46 \\
(8.06) \\
b\end{array}$ & $\begin{array}{c}57.36 \\
(10.41) \\
b\end{array}$ & $\begin{array}{c}47.84 \\
(10.97) \\
b\end{array}$ & $\begin{array}{c}\mathrm{F}=26.22 * * \\
(.000)\end{array}$ & $\begin{array}{c}\mathrm{F}=3.09 \\
(.060)\end{array}$ & $\begin{array}{l}\mathrm{F}=.57 \\
(.568)\end{array}$ \\
\hline & $\mathrm{K} / \mathrm{S}$ & $\begin{array}{c}4.11 \\
(.19) \\
a\end{array}$ & $\begin{array}{c}8.72 \\
(2.98) \\
\mathrm{b}\end{array}$ & $\begin{array}{c}7.37 \\
(1.80) \\
b\end{array}$ & 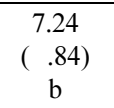 & $\begin{array}{c}\chi^{2}=15.55^{* *} \\
(.001)\end{array}$ & $\begin{array}{c}F=1.75 \\
(.190)\end{array}$ & $\begin{array}{l}\mathrm{F}=.87 \\
(.428)\end{array}$ \\
\hline & $\Delta E$ & $\begin{array}{c}69.39 \\
(6.29) \\
\mathrm{a}\end{array}$ & $\begin{array}{c}85.28 \\
(3.26) \\
b\end{array}$ & $\begin{array}{c}83.40 \\
(3.12) \\
\mathrm{bc}\end{array}$ & $\begin{array}{c}79.43 \\
(4.16) \\
c\end{array}$ & $\begin{array}{c}\chi^{2}=19.97 * * \\
(.000)\end{array}$ & $\begin{array}{c}\mathrm{F}=2.92 \\
(.070)\end{array}$ & $\begin{array}{c}\mathrm{F}=3.05 \\
(.062)\end{array}$ \\
\hline \multirow{3}{*}{$\begin{array}{l}\text { Palmatine- } \mathrm{CH} \\
\qquad(\mathrm{N}=33)\end{array}$} & $\begin{array}{c}\text { Dye } \\
\text { exhaustion }\end{array}$ & $\begin{array}{c}70.61 \\
(4.32) \\
\mathrm{a}\end{array}$ & $\begin{array}{c}64.99 \\
(9.65) \\
a\end{array}$ & $\begin{array}{c}81.31 \\
(12.24) \\
b\end{array}$ & $\begin{array}{c}80.76 \\
(3.35) \\
b\end{array}$ & $\begin{array}{c}\chi^{2}=14.71 * * \\
(.002)\end{array}$ & $\begin{array}{c}\mathrm{F}=7.30 * * \\
(.003)\end{array}$ & $\begin{array}{l}\mathrm{F}=.17 \\
(.845)\end{array}$ \\
\hline & $\mathrm{K} / \mathrm{S}$ & $\begin{array}{c}3.32 \\
\left(\begin{array}{l}.42 \\
\mathrm{a}\end{array}\right.\end{array}$ & $\begin{array}{c}3.54 \\
\left(\begin{array}{c}.67) \\
\mathrm{ab}\end{array}\right.\end{array}$ & $\begin{array}{c}4.43 \\
(1.03) \\
b c\end{array}$ & $\begin{array}{c}4.79 \\
(1.13) \\
c\end{array}$ & $\begin{array}{c}\mathrm{F}=4.88 * * \\
(.007)\end{array}$ & $\begin{array}{c}\mathrm{F}=10.77 * * \\
(.000)\end{array}$ & $\begin{array}{l}\mathrm{F}=.38 \\
(.684)\end{array}$ \\
\hline & $\Delta E$ & $\begin{array}{c}62.23 \\
(1.59) \\
\mathrm{a}\end{array}$ & $\begin{array}{c}64.08 \\
(3.94) \\
a b\end{array}$ & $\begin{array}{c}67.81 \\
(6.21) \\
b\end{array}$ & $\begin{array}{c}68.17 \\
(3.67) \\
b\end{array}$ & $\begin{array}{c}\chi^{2}=9.40^{*} \\
(.024)\end{array}$ & $\begin{array}{c}\chi^{2}=23.44^{* *} \\
\quad(.000)\end{array}$ & $\begin{array}{l}\mathrm{F}=.49 \\
(.620)\end{array}$ \\
\hline \multirow{3}{*}{$\begin{array}{c}\text { Phellodendron } \\
\text { bark } \\
(\mathrm{N}=33)\end{array}$} & $\begin{array}{c}\text { Dye } \\
\text { exhaustion }\end{array}$ & $\begin{array}{c}14.37 \\
(11.50) \\
\mathrm{a}\end{array}$ & $\begin{array}{c}56.46 \\
(8.06) \\
b\end{array}$ & $\begin{array}{c}57.36 \\
(10.41) \\
b\end{array}$ & $\begin{array}{c}47.84 \\
(10.97) \\
b\end{array}$ & $\begin{array}{c}\mathrm{F}=26.22 * * \\
(.000)\end{array}$ & $\begin{array}{c}\mathrm{F}=3.09 \\
(.060)\end{array}$ & $\begin{array}{c}\mathrm{F}=.577 \\
(.568)\end{array}$ \\
\hline & $\mathrm{K} / \mathrm{S}$ & $\begin{array}{c}7.69 \\
(4.16)\end{array}$ & $\begin{array}{c}107.51 \\
(133.17)\end{array}$ & $\begin{array}{c}553.27 \\
(1374.45)\end{array}$ & $\begin{array}{c}88.82 \\
(164.83)\end{array}$ & $\begin{array}{c}\chi^{2}=17.62^{* *} \\
(.001)\end{array}$ & $\begin{array}{c}\chi^{2}=7.81^{*} \\
(.020)\end{array}$ & $\begin{array}{c}\chi^{2}=5.79 \\
(.055)\end{array}$ \\
\hline & $\Delta E$ & $\begin{array}{c}69.39 \\
\left(\begin{array}{c}6.29) \\
\mathrm{a}\end{array}\right)\end{array}$ & $\begin{array}{c}85.28 \\
\left(\begin{array}{c}3.26) \\
b\end{array}\right.\end{array}$ & $\begin{array}{c}83.40 \\
\left(\begin{array}{l}3.12) \\
\text { bc }\end{array}\right.\end{array}$ & $\begin{array}{c}79.29 \\
\left(\begin{array}{c}4.16) \\
c\end{array}\right.\end{array}$ & $\begin{array}{c}\mathrm{F}=19.97 * * \\
\quad(.000)\end{array}$ & $\begin{array}{c}\mathrm{F}=2.92 \\
(.070)\end{array}$ & $\begin{array}{c}\mathrm{F}=3.05 \\
(.062)\end{array}$ \\
\hline
\end{tabular}

${ }^{1)}$ Kruskal Wallis $\left(\chi^{2}\right)$ test was conducted instead of ANOVA (F value) when the Levene's test for the equality of variances was rejected.

${ }^{2}$ Mean value and the standard deviation in parenthesis.

${ }^{3)}$ Different alphabet in the cell indicates different groups according to the Duncan test. 
uptake were observed with the dyeing time of $30 \mathrm{~min}$ and $60 \mathrm{~min}$.

The above results indicate that the dye exhaustion and dye uptake of palmatine- $\mathrm{CH}$ are slightly lower than that of berberine-C, which however were not statistically significant. Like berberine-C, palmatine$\mathrm{CH}$ favored $\mathrm{pH} 7$ condition for both dye exhaustion and dye uptake. However, palmatine-CH favors higher dyeing temperature and longer dyeing time than berberine-C for better dyeing results.

\section{Colorfastness Test}

The silk samples dyed with all three dyes faded badly by washing but they exhibited excellent colorfastness to drycleaning (Table 8). Among the three dyes, palmatine- $\mathrm{CH}$ showed the lowest colorfastness to sunlight. All three dyes showed excellent color- fastness to perspiration.

\section{Conclusions}

The purpose of this research was to investigate the dyeing behaviors of berberine, palmatine, and the dye extracted from Phellodendron bark on silk fabric with the intention of evaluating palmatine as another chromophoric substance of Phellodendron bark. From the present results and based on the review of previous literatures on the percent composition of berberine and palmatine in the plant, it is clear that palmatine as well as berberine contributes in the yellow dyeing of Phellodendron bark extract. The experimental results suggested that palmatine was comparable to berberine in the dyeing behaviors tested for this study and the results were proven to be statistically significant. The dye exhaustion and dye uptake of palma-

Table 7. Statistical analyses of palmatine- $\mathrm{CH}$ on the effect of dyeing time without $\mathrm{pH} 3$ data

\begin{tabular}{|c|c|c|c|c|c|}
\hline \multirow{2}{*}{ Dye } & \multirow{2}{*}{ Factor } & \multicolumn{3}{|c|}{ Dyeing time (min) } & \multirow{2}{*}{$\begin{array}{l}\text { Statistics } \\
\text { (p-value) }\end{array}$} \\
\hline & & 10 & 30 & 60 & \\
\hline \multirow{3}{*}{$\begin{array}{c}\text { Palmatine-CH } \\
\qquad(\mathrm{N}=33)\end{array}$} & Dye exhaustion & $\begin{array}{c}66.70^{1)} \\
(10.58) \\
a^{2)}\end{array}$ & $\begin{array}{c}78.55 \\
(89.00) \\
\text { b }\end{array}$ & $\begin{array}{c}80.46 \\
\left(\begin{array}{c}7.36) \\
\mathrm{b}\end{array}\right.\end{array}$ & $\begin{array}{c}\mathrm{F}=7.30 * * \\
(.003)\end{array}$ \\
\hline & $\mathrm{K} / \mathrm{S}$ & $\begin{array}{c}3.21 \\
\left(\begin{array}{c}.61) \\
\mathrm{a}\end{array}\right. \\
\end{array}$ & $\begin{array}{c}4.51 \\
\left(\begin{array}{c}.91 \\
\mathrm{~b}\end{array}\right)\end{array}$ & $\begin{array}{c}4.68 \\
\left(\begin{array}{c}.95) \\
\mathrm{b}\end{array}\right.\end{array}$ & $\begin{array}{c}\mathrm{F}=10.77 * * \\
(.000)\end{array}$ \\
\hline & $\Delta E$ & $\begin{array}{c}61.20 \\
(3.22) \\
a\end{array}$ & $\begin{array}{c}67.34 \\
(3.00) \\
b\end{array}$ & $\begin{array}{c}70.15 \\
(3.10) \\
c\end{array}$ & $\begin{aligned} \mathrm{F}= & 23.44^{* *} \\
& (.000)\end{aligned}$ \\
\hline
\end{tabular}

${ }^{10}$ Mean value and the standard deviation in parenthesis.

${ }^{2)}$ Different alphabet in the cell indicates different groups according to the Duncan test.

Table 8. Colorfastness grades of berberine- $\mathrm{C}$, palmatine- $\mathrm{CH}$, and Phellodendron bark dyed silk towards washing, sunlight, perspiration, and dry-cleaning

\begin{tabular}{|c|c|c|c|c|c|c|c|c|c|c|c|}
\hline \multirow{2}{*}{\multicolumn{2}{|c|}{ Colorfastness }} & \multirow{2}{*}{ Type } & \multicolumn{3}{|c|}{ Berberine-C } & \multicolumn{3}{|c|}{ Palmatine-CH } & \multicolumn{3}{|c|}{ Phellodendron bark } \\
\hline & & & pH 5 & pH 7 & pH 9 & $\mathrm{pH} 5$ & pH 7 & pH 9 & $\mathrm{pH} 5$ & pH 7 & $\mathrm{pH} 9$ \\
\hline \multirow{2}{*}{\multicolumn{2}{|c|}{ Washing }} & Fading & 1 & 1 & 1 & 1 & 1 & 1 & $1-2$ & $1-2$ & $1-2$ \\
\hline & & Staining & 4 & 4 & 4 & 4 & 4 & 4 & $3-4$ & $3-4$ & 3 \\
\hline \multicolumn{2}{|c|}{ Sunlight } & Fading & $1-2$ & $1-2$ & $1-2$ & 1 & 1 & 1 & 2 & 2 & 2 \\
\hline \multirow{4}{*}{ Perspiration } & \multirow{2}{*}{ Acid } & Fading & $4-5$ & $4-5$ & $4-5$ & $4-5$ & $4-5$ & $4-5$ & 5 & $4-5$ & $4-5$ \\
\hline & & Staining & 4 & 4 & $3-4$ & 4 & $4-5$ & 4 & 4 & 3 & 3 \\
\hline & \multirow{2}{*}{ Base } & Fading & $4-5$ & $4-5$ & $4-5$ & $4-5$ & $4-5$ & $4-5$ & $4-5$ & $4-5$ & $4-5$ \\
\hline & & Staining & 4 & $3-4$ & 4 & 4 & 4 & 4 & $3-4$ & $3-4$ & $3-4$ \\
\hline \multicolumn{2}{|c|}{ Dry-cleaning } & Fading & 5 & 5 & 5 & 5 & 5 & 5 & 5 & 5 & $4-5$ \\
\hline
\end{tabular}


tine-CH were slightly lower than that of berberine-C, which however were not statistically significant. Palmatine- $\mathrm{CH}$ favors higher dyeing temperature and longer dyeing time than berberine-C for better dyeing results. Like berberine-C, palmatine- $\mathrm{CH}$ favored $\mathrm{pH}$ 7 condition for both dye exhaustion and dye uptake. Since $\mathrm{pH} 7$ is the unadjusted natural $\mathrm{pH}$ of the two dyes in water, palmatine as well as berberine can be used efficiently as the pure natural dye source without using $\mathrm{pH}$ adjusting chemicals.

\section{References}

Ahn, C. (2011). Analysis of dye extracted from Phellodendron bark using liquid chromatography. Journal of the Korean Society of Clothing and Textiles, 35(12), $1507-$ 1517.

Ahn, C., Zeng, X., \& Obendorf, S. K. (2012). Analysis of dye extracted from Phellodendron bark and its identification in archaeological textiles. Textile Research Journal, 82(16), 1645-1658.

Battu, S. K., Renka, M. A., Maddineni, S., Chittiboyina, A. G., Avery, M. A., \& Majumdar, S. (2010). Physicochemical characterization of berberine chloride: A perspective in the development of a solution dosage form for oral delivery. AAPS PharmSciTech, 11(3), 1466-1475.

Chan, C. O., Chu, C. C., Mok, D. K. W., \& Chau, F. T. (2007). Analysis of berberine and total alkaloid content in Cortex Phellodendri by near infrared spectroscopy (NIRS) compared with high-performance liquid chromatography coupled with ultra-visible spectrometric detection. Analytica Chimica Acta, 592(2), 121-131.

Cho, K. R., \& Kang, M. J. (2000). Studies on the natural dyes (12)-Dyeing properties of amur cork tree colors for silk-. Journal of the Korean Society of Dyers and Finishers, 12(4), 13-21.

Chromadex, Inc. (2011). Tech tip 0013: Hydrates and salts. Tech tips. Retrieved July 5, 2012, from https://chromadex.com/wpresources/Upload/Article/HydratesandSaltsTechTip0013.pdf

Grycova, L., Dostal, J., \& Marek, R. (2007). Quaternary protoberberine alkaloids. Phytochemistry, 68(2), 150-175.

Hu, Y. M., Su, G. H., Sze, S. C. W., Ye, W., \& Tong, Y. (2010). Quality assessment of Cortex Phellodendri by high-performance liquid chromatography coupled with electrospray ionization mass spectrometry. Biomedical Chromatography, 24(4), 438-453.

HunterLab. (2008). The Kubelka-Munk theory and K/S. Applications Note, 18(7), 1-3.
Kim, H. I., \& Park, S. M. (2007). Effects of introduced chemical groups on the dyeability of cotton fabrics with Phellodendron amurense Rupr. Dyes and Pigments, 75 (2), 351-355.

Kim, T. K., \& Son, Y. A. (2005). Effect of reactive anionic agent on dyeing of cellulosic fibers with a berberine colorant-part 2: Anionic agent treatment and antimicrobial activity of a berbrine dyeing. Dyes and Pigments, 64(1), 85-89.

Kim, T. K., Yoon, S. H., \& Son, Y. A. (2004). Effect of reactive anionic agent on dyeing of cellulosic fibers with a berberine colorant. Dyes and Pigments, 60(2), 121-127.

Lee, J. G., Choi, J. Y., Oh, J. S., Jung, H. W., Choi, E. H., Lee, H. S., Kim, J. A., Chang, T. S., Son, J. K., \& Lee, S. H. (2007). Isolation of melanin biosynthesis inhibitory compounds from the Phellodendri Cortex. Korean Journal of Pharmacognosy, 38(4), 387-393.

Lee, H. S., Eom, Y. E., \& Eom, D. O. (1999). Narrowbore high performance liquid chromatography of berberine and palmatine in crude drugs and pharmaceuticals with ion-pair extraction using cobalt thiocyanate reagent. $\mathrm{Jo}_{\mathrm{O}}$ urnal of Pharmaceutical and Biomedical Analysis, 21 (1), 59-63.

Li, X., Liu, H., Li, J., Zhao, X., Wang, S. \& Zheng, X. (2009). Simultaneous determination of berberine and palmatine in rabbit plasma by LC-MS-MS and its application in pharmacokinetic study after oral administration of Coptidis and Coptidis-Gardeniae couple extract. Chromatographia, 70(7/8), 1113-1119.

LKT Laboratories. (2010). Palmatine chloride hydrate. $L K T$ Laboratories, Inc. Specialty Biochemical Resource. Retrieved January 9, 2012, from http://www.lktlabs.com/ products/Palmatine_Chloride_Hydrate-345-23.html

Santa Cruz Biotechnology, Inc. (2007-2012). Product block: palmatine-CHloride hydrate: sc-205788. Santa Cruz Biotechnology, Inc. Retrieved January 9, 2012, from http:// www.scbt.com/datasheet-205788-palmatine-chloride-hydrate.html

Shaanxi Hongkang Biological Technology Co., Ltd., (19992010). $98 \%$ high jatrorrhizine of plant extract. Alibaba. Retrieved December 17, 2012, from http://www.alibaba. com/product-qs/373522585/Jatrorrhizine_of_98_html

Suto, K., Kakinuma, S., Ito, Y., Sagara, K., Iwasaki, H., \& Itokawa, H. (1997). Determination of berberine and palmatine in Phellodendri Cortex using ion-pair supercritical fluid chromatography on-line coupled with ionpair supercritical fluid extraction by on-column trapping. Journal of Chromatography A, 786(2), 371-376.

Wei, W., Luo, G. A., Hua, G. Y., \& Yan, C. (1998). Capillary electrochromatographic separation of basic compounds with bare silica as stationary phase. Journal of Chromatography A, 817(1-2), 65-74. 